\title{
Bone histology of eosauropterygian diapsid Proneusticosaurus silesiacus from the Middle Triassic of Poland reveals new insights into taxonomic affinities
}

\author{
Nicole Klein and Dawid Surmik \\ Acta Palaeontologica Polonica 66 (3), 2021: 585-598 doi:https://doi.org/10.4202/app.00850.2020
}

The status of Proneusticosaurus silesiacus from the Lower Muschelkalk (lower Anisian) of Poland is controversially discussed. Its femur was histologically sampled to learn more about its taxonomic affinities and life style. It shows a reduced central medullary cavity surrounded by a narrow medullary region and followed by a thick compact cortex, displaying strong osteosclerosis. The tissue type can be summarized as lamellar-zonal. The inner third of the cortex consists of well vascularized parallel-fibred bone and is interpreted as a phase of juvenile growth, whereas the middle and outer cortex is made of highly organized parallel-fibred to lamellar bone. Except for the inner cortex and local accumulations of longitudinally primary osteons in the middle cortex, the femur is widely avascular. The cortex of $P$. silesiacus is regularly stratified by rest lines. Altogether seven annual growth cycles are counted. The very low growth rate of $P$. silesiacus, as deduced from tissue type, makes taxonomical affinities to Nothosaurus spp. or basal pistosauroids (i.e., humeri of aff. Cymatosaurus sp.) very unlikely. Proneusticosaurus silesiacus femoral histology does also not match any of the here studied femora of Eosauropterygia indet. Proneusticosaurus silesiacus shares similar low growth rates, the osteosclerotic femur, as well as pachyostotic vertebrae and ribs with the pachypleurosaurs Dactylosaurus gracilis and Neusticosaurus spp. and with the nothosaur Lariosaurus sp. These features are, however, most likely convergent and reflect the degree of secondary aquatic adaptation in shallow marine inhabitants. The high organized and low vascularized tissue, the implied low growth rate, the plesiomorphic femur morphology, and the strongly inclined zygapophyses of the vertebrae (contra roughly horizontal zygapophyses in other Eosauropterygia), makes $P$. silesiacus unique and evidence that this genus represents a valid genus within early Eosauropterygia. Proneusticosaurus silesiacus might represent one of the most basal members of Eosauropterygia so far known.

Key words: Sauropsida, aquatic adaptation, bone histology, marine reptiles, morphology, aquatic adaptation, Lower Muschelkalk, Poland.

Nicole Klein [nklein@posteo.de], Institute of Geosciences, Palaeontology, University of Bonn, Nußallee 8, 53115 Bonn, Germany. Dawid Surmik [dawid.surmik@us.edu.pl], Institute of Earth Sciences, Faculty of Natural Sciences, University of Silesia, Ul. Bedzinska 60, 41-200 
Sosnowiec.

This is an open-access article distributed under the terms of the Creative Commons Attribution License (for details please see creativecommons.org), which permits unrestricted use, distribution, and reproduction in any medium, provided the original author and source are credited.

Full text $(2,680.7 \mathrm{kB})$
Supplementary file $(3,858.5 \mathrm{kB})$ 